\title{
Phase 1/2 study of alectinib in RET-rearranged previously-treated non-small cell lung cancer (ALL-RET)
}

\author{
Shinji Takeuchi ${ }^{1,2}$, Noriko Yanagitani ${ }^{3}$, Takashi Seto ${ }^{4}$, Yoshihiro Hattori ${ }^{5}$, Kadoaki Ohashi ${ }^{6}$, \\ Masahiro Morise ${ }^{7}$, Shingo Matsumoto ${ }^{8}$, Kiyotaka Yoh $^{8}$, Koichi Goto ${ }^{8}$, Makoto Nishio ${ }^{3}$, \\ Shizuko Takahara ${ }^{9}$, Takahiro Kawakami ${ }^{9}$, Yasuhito Imai ${ }^{9}$, Kenichi Yoshimura ${ }^{9,10}$, Azusa Tanimoto ${ }^{1,2}$, \\ Akihiro Nishiyama ${ }^{1,2}$, Toshinori Murayama ${ }^{9}$, Seiji Yano ${ }^{1,2}$
}

${ }^{1}$ Division of Medical Oncology, Cancer Research Institute, Kanazawa University, Kanazawa, Ishikawa, Japan; ${ }^{2}$ Cancer Center, Kanazawa University Hospital, Kanazawa, Ishikawa, Japan; ${ }^{3}$ Department of Thoracic Medical Oncology, The Cancer Institute Hospital of Japanese Foundation for Cancer Research, Koto-ku, Tokyo, Japan; ${ }^{4}$ Department of Thoracic Oncology, National Kyusyu Cancer Center, Minami-Ku, Fukuoka, Japan; ${ }^{5}$ Department of Thoracic Oncology, Hyogo Cancer Center, Akashi, Hyogo, Japan; ${ }^{6}$ Department of Respiratory Medicine and Allergy, Kita-ku, Okayama University Hospital, Okayama, Japan; ${ }^{7}$ Department of Respiratory Medicine, Nagoya University Graduate School of Medicine, Nagoya, Aichi, Japan; ${ }^{8}$ Department of Thoracic Oncology, National Cancer Center Hospital East, Kashiwa, Chiba, Japan; ${ }^{9}$ Innovative Clinical Research Center (iCREK), Kanazawa University Hospital, Kanazawa, Ishikawa, Japan; ${ }^{10}$ Medical Center for Translational and Clinical Research, Hiroshima University Hospital, Hiroshima University, Minami, Hiroshima, Japan

Contributions: (I) Conception and design: S Takeuchi, K Goto, M Nishio, K Yoh, K Yoshimura, T Murayama, S Yano; (II) Administrative support: S Yano; (III) Provision of study materials or patients: S Takeuchi, N Yanagitani, T Seto, Y Hattori, K Ohashi, M Morise, S Matsumoto, K Yoh, K Goto, M Nishio, A Tanimoto, A Nishiyama; (IV) Collection and assembly of data: S Takeuchi, T Kawakami, Y Imai; (V) Data analysis and interpretation: S Takeuchi, K Yoh, S Takahara, Y Imai; (VI) Manuscript writing: All authors; (VII) Final approval of manuscript: All authors.

Correspondence to: Seiji Yano. Division of Medical Oncology, Cancer Research Institute, Kanazawa University, 13-1 Takara-machi, Kanazawa, Ishikawa 920-0934, Japan. Email: syano@staff.kanazawa-u.ac.jp.

Background Rearranged during transfection (RET) rearrangements occur in 1-2\% of non-small cell lung cancers (NSCLCs). Alectinib administered at doses of $300 \mathrm{mg}$ and $600 \mathrm{mg}$ twice daily (BID) is approved for $A L K$-rearranged NSCLC in Japan and other countries, respectively. Since alectinib has activity against RET, we conducted a phase (P) 1/2 study of alectinib to determine its activity in Japanese patients with RETrearranged NSCLC.

Methods: This study was a single-arm, open-label, multi-institutional P1/2 trial. Previously treated patients with RET-rearranged NSCLC, screened by nation-wide network (LC-SCRUM-Japan), were recruited. In P1, alectinib (600 or $450 \mathrm{mg}$ BID) was administered following a 3+3 design and its safety was assessed. During P2, alectinib was administered at the recommended dose (RD) determined in P1. The primary endpoint was the objective response rate (ORR) in RET inhibitor-naïve patients treated with the RD of alectinib.

Results: Thirty-four patients were administered alectinib. In cohort 1 (600 mg BID) of P1, we observed 5 dose-limiting toxicities (DLTs), including grade 3 rash and thromboembolic event, in 3 of 6 patients. In cohort 2 (450 mg BID), we observed no DLTs in 3 patients. Pharmacokinetic analysis revealed that $\mathrm{AUC}_{0-10}$ to $600 \mathrm{mg}$ BID was higher than that previously reported in global trials. We determined $450 \mathrm{mg}$ BID as the RD for P2. In 25 RET inhibitor-naïve patients, one achieved an objective response (4\%) and 13 achieved disease control at 8 weeks (52\%). The median progression-free survival (PFS) was 3.4 months (95\% CI, 2.0-5.4), while the median overall survival was 19.0 months (5.4-NE). We observed grade 3 adverse events (AEs) (4\%) including pneumonitis in P2.

Conclusions: Alectinib exerts limited activity against RET-rearranged NSCLC. Further investigation to elucidate the mechanisms underlying sensitivity and resistance of RET inhibitors is required to improve outcomes for these patients. 
Keywords: Rearranged during transfection (RET); RET rearrangement; lung cancer; alectinib; clinical trial; precision medicine

Submitted Apr 10, 2020. Accepted for publication Sep 30, 2020.

doi: $10.21037 /$ tlcr-20-549

View this article at: http://dx.doi.org/10.21037/tlcr-20-549

\section{Introduction}

Lung cancer is the leading cause of cancer deaths worldwide. Histologically, it is subdivided into small cell lung cancer and non-small cell lung cancer (NSCLC). NSCLC accounts for $\sim 80 \%$ of cases of lung cancers, with adenocarcinoma being the most frequent subtype. Several driver oncogenes and mutations, such as epidermal growth factor receptor (EGFR) mutations in $40 \%$ to $55 \%$ cases, anaplastic lymphoma kinase (ALK) rearrangement in $3 \%$ to $5 \%$ cases, ROS1 rearrangement in $2 \%$ to $3 \%$ cases, v-raf murine sarcoma viral oncogene homolog B1 (BRAF) mutation in $0.5 \%$ to $1 \%$ cases, and neurotrophic tropomyosin receptor kinase (NTRK) rearrangement in $1 \%$ or fewer cases, have been identified in East Asian lung adenocarcinoma patients (1). Individualized therapy based on gene profiling with corresponding targeted drugs has been introduced into clinical practice (2-8). Rearranged during transfection (RET) is an oncogene discovered in 1985 during the transfection of NIH 3T3 cells with human lymphoma DNA (9). RET rearrangement is detected in $20-40 \%$ of papillary thyroid cancers $(10,11)$ and has been identified in some cases of NSCLCs (12-15). The most common fusion partners of RET are $K I F 5 B$, followed by CCDC6, TRIM33, and NCOA4 (14,16,17). RET rearrangement has been detected in 1-2\% of NSCLCs and mutation or rearrangement of other commonly-altered genes, including EGFR, KRAS, ALK and ROS1 are mutually exclusive events (14). Transgenic mice expressing the KIF5B-RET fusion gene develop lung adenocarcinoma (18), indicating that $R E T$ rearrangement is one of the oncogenic drivers of lung adenocarcinoma.

Recent clinical trials demonstrated the modest efficacy of vandetanib or cabozantinib in $R E T$-rearranged NSCLC. Patients treated with vandetanib had a response rate of $53 \%$ ( $9 / 17$ cases) and a median progression-free survival (PFS) of 4.7 months (19); those treated with cabozantinib had a response rate of $28 \%$ ( $7 / 25$ cases) and a median PFS of 5.5 months (20). These results demonstrate that the efficacy of these drugs was lower compared to those in NSCLC cases with EGFR mutations or ALK rearrangement treated with EGFR-tyrosine kinase inhibitors (TKIs) or ALK-TKIs (2-6), respectively, highlighting the need for further development of RET inhibitors for the treatment of RET-rearranged NSCLC.

Alectinib (CH5424802) is a second generation ALKTKI (21) which has been approved for $A L K$-rearranged NSCLC. In addition to high activity against ALK, alectinib has inhibitory activity toward RET kinase (half maximum inhibitory concentrations $\left(\mathrm{IC}_{50}\right)$ for ALK kinase and RET kinase are $1.9 \mathrm{nmol} / \mathrm{L}$ and $4.8 \mathrm{nmol} / \mathrm{L}$, respectively) $(20,21)$. Pre-clinical studies reported that alectinib did inhibit the growth of RET-rearranged tumor cells in vitro and in vivo $(22,23)$, suggesting the potential activity of alectinib against RET-rearranged NSCLC patients.

In a Japanese phase 1 trial in $A L K$-rearranged NSCLC patients, alectinib at $300 \mathrm{mg}$ twice a day (BID) showed remarkable efficacy with a response rate of $93.5 \%$ and median PFS of longer than 27 months without any dose-limiting toxicity (DLT) (24). Alecensa formulation contains $50 \%$ sodium lauryl sulfate (SLS) as an excipient in comparison to alectinib. The maximum dose of SLS for drugs that had been approved before was $300 \mathrm{mg}$ per day in Japan. Therefore, the sponsor determined that $300 \mathrm{mg}$ BID of Alecensa ( $=300 \mathrm{mg}$ of SLS) as the maximum dose per day would be appropriate. Accordingly, $300 \mathrm{mg}$ BID of alectinib was approved for $A L K$-rearranged NSCLC in Japan. Contrastingly, global trials, including AF-002JG, have reported the efficacy and safety of alectinib escalated until $900 \mathrm{mg}$ BID, and the U.S. Food and Drug Administration (FDA) approved $600 \mathrm{mg}$ BID of alectinib for $A L K$ rearranged NSCLC $(25,26)$. Thus, we sought to determine maximum tolerate dose (MTD) of alectinib in Japanese patients and assess the maximum efficacy of alectinib in RET-rearranged NSCLC. We conducted a phase 1/2 study to determine the objective response rate (ORR) at doses higher than $300 \mathrm{mg}$ BID in Japanese patients with RETrearranged NSCLC (ALL-RET trial: alectinib in lung cancer with RET fusion) (27), as the investigator initiated trial. 
We present the following article in accordance with the TREND guideline checklist (available at http://dx.doi. org/10.21037/tlcr-20-549).

\section{Methods}

\section{Study design}

We conducted an open-label, multi-institutional phase $1 / 2$ study involving 7 specialized centers in Japan as of January 2016 (27). The primary endpoint was to establish the maximum tolerated dose in the phase 1 and ORR in RET-TKI-naive patients treated with the recommended dose (RD) of alectinib in the phase 2 portion and phase 1 portion, according to a central review.

The secondary endpoints were PFS, disease control rate (DCR), overall survival (OS), ORR in patients previously treated with RET-TKIs, subgroup efficacy in patients harboring different $R E T$-fusion partners, and safety.

\section{Statistical analysis}

In phase 1 , the sample size was determined based on a $3+3$ phase 1 design for oncology drugs. In phase 2 , the planned sample size of 17 RET-TKI-naïve patients was determined to reject a null ORR of $30 \%$ at a one-sided significance level of 0.05 under an expected ORR of $60 \%$ with a power of 0.80 . In addition, a maximum of 10 patients previously treated with other RET-TKIs were also enrolled for exploratory analysis in phase 2 . In phase 1 , the DLT rate was evaluated using a $3+3$ design, and the RD was determined. All patients in phase 2 and RET-TKI-naïve patients treated with RD of alectinib in phase 1 were included for phase 2 efficacy analysis. We estimated the confidence interval (CI) of the ORR based on the exact binomial distribution with a onesided significance level of $5 \%$. In phase 2 , the treatment was deemed promising if the estimated lower limit of the ORR exceeded the threshold value of $30 \%$. Statistical analysis was performed using SAS version 9.4 (SAS Institute, Cary, NC).

\section{Patients}

RET rearrangements were screened using a nationwide genomic screening network (LC-SCRUM-Japan) of about 200 participating institutions (19). RET rearrangements were identified by three different methods, including multiplex reverse transcriptase PCR (RT-PCR), a breakapart fluorescence in-situ hybridization (FISH) assay, and targeted next-generation sequencing (NGS) systems (Oncomine Cancer Research Panel or Oncomine Comprehensive Assay). In this study, patients whose tumor was $R E T$-rearrangement positive by at least 2 methods were defined as eligible. Other eligibility criteria included written informed consent; aged 20 years or older; histological or cytological diagnosis of NSCLC with unresectable locally advanced or metastatic disease; tumor samples that test positive for a $R E T$ rearrangement and test negative for EGFR mutation and $A L K$ rearrangement; previously treated with at least one regimen of chemotherapy; life expectancy of 3 months or longer; Eastern Cooperative Oncology Group (ECOG) Performance Status (PS) of 0-2; test negative for pregnancy; having adequate bone marrow, liver, renal, and respiratory functions as follows: (I) neutrophil count $\geq 1,500 / \mathrm{mm}^{3}$, (II) hemoglobin level $\geq 9.0 \mathrm{~g} / \mathrm{dL}$, (III) platelet count $\geq 100,000 / \mathrm{mm}^{3}$, (IV) serum creatinine level $\leq 1.5 \mathrm{mg} / \mathrm{dL}$, (V) ALT, AST, and ALP levels $\leq 3$-fold of the upper limit of the reference value at each institution, (VI) serum bilirubin level $\leq 1.5$-fold of the upper limit of the reference value at each institution, (VII) $\mathrm{SpO}_{2} \geq 92 \%$, and having one or more measurable lesions in accordance with the revised RECIST guidelines (version 1.1).

Patients were excluded for any of the reasons shown in the exclusion criteria as follows, having previously received alectinib; having a history of hypersensitivity to additives contained in alectinib; having an infection requiring systemic administration of antibiotics or antivirals; laboratory results positive for hepatitis B antigen or anti-hepatitis $\mathrm{C}$ virus antibodies; having unstable brain metastases or spinal cord compression that requires treatment; having a condition that would preclude receipt of the study treatment; having a QTc interval greater than $480 \mathrm{~ms}$, a history of long QT syndrome, a history of clinically significant ventricular arrhythmia, currently receiving antiarrhythmic drugs, or having an implanted defibrillator; having interstitial lung disease or a history of that disease; having poorly controlled diabetes or hypertension that cannot be managed with medication; patients who would have difficulty taking medication orally; exhibiting adverse reactions prior to treatment that are grade 2 or more severe; if the following times have not elapsed from prior to treatment or the conclusion of treatment upon enrollment in this study: (I) surgery or radiation therapy: 4 weeks, (II) bronchoscopic treatment: 2 weeks (III) chemotherapy: 4 weeks, (IV) lenvatinib or vandetanib: 3 weeks, (V) nitrosourea or MMC: 6 weeks, (VI) endocrine therapy or immunotherapy: 2 weeks, (VII) 
transfusion or a hematopoietic growth factor: 2 weeks, (VIII) other trial medications: 4 weeks; patients with pleural effusion, pericardial effusion, or ascites requiring treatment; a deep vein thrombus or pulmonary thromboembolism that requires treatment; multiple malignancies with differing histologies; patients with a history of other malignancies in the past 5 years; or patients whom an investigator deems ineligible for participation in this study for some other reason.

\section{Treatment and assessments}

Alectinib was kindly provided by Chugai Pharmaceutical. Alectinib was administered orally twice per day within 30 minutes after a meal (once in the morning and once in the evening). In phase 1, alectinib (cohort 1: $600 \mathrm{mg}$, cohort 2: $450 \mathrm{mg}$ ) was administered in a 21-day cycle until the criteria for respite, dosage reduction, or discontinuation of the treatment protocol were met. Three to six patients were enrolled in each cohort. The RD or MTD of alectinib was determined using a de-escalation scheme (Figure S1). In phase 2, the RD/MTD of alectinib in a 21-day cycle was continued until the criteria for a respite, dosage reduction, or discontinuation of the treatment protocol were met.

Toxicities were assessed according to version 4.0 of the National Cancer Institute Common Terminology Criteria for Adverse Events (CTCAE). DLT is defined as follows: grade $\geq 4$, thrombopenia; grade $\geq 3$, febrile neutropenia; grade $\geq 4$, neutropenia lasting 4 or more days; grade $\geq 3$, any non-hematologic toxicity except for controllable electrolyte abnormality, nausea, vomiting, and diarrhea. DLT was evaluated during the first cycle of therapy ( 21 days). After completion of protocol treatment, the patients were followed-up until January 2019.

We assessed objective tumor response in accordance with version 1.1 of the revised Response Evaluation Criteria in Solid Tumors (RECIST) guideline (28). At baseline, we imaged the chest (CT), abdomen (CT), pelvis (CT or MRI), brain (CT or MRI), and bone (CT, bone scintigraphy, or FDG-PET scan) within 28 days before entry in this trial. After the start of treatment, the assessments were performed on day 21 and then every 6 weeks throughout the study. An independent response evaluation committee consisting of two radiologists at each session reviewed images of patients; reviewers were blinded from the investigators' assessment and dose of alectinib. PFS was defined as the time from the start of alectinib treatment to the first instance of progression or death. OS was defined as the time from the start of alectinib treatment to death. DCR was defined as the proportion of patients who achieved complete response, partial response, and stable disease for at least 8 weeks.

\section{Pharmacokinetic analysis}

Blood samples were obtained prior to treatment and $0.5,1$, 2, 4, 6, 8, and $10 \mathrm{~h}$ after drug administration on days 1 and 15 in cycle 1 . Alectinib concentrations were quantified using a liquid chromatography-mass spectrometry method with a lower detection limit of $0.10 \mathrm{ng} / \mathrm{mL}$ (29).

\section{Quality control}

All the data were collected via book-type Case Record Form and managed by an independent data center. The quality of study was controlled by on-site monitoring including source document verification. All recruited patients were followedup and their data were analyzed according to the Intentto-Treat principle. All patients in phase 2 and RET-TKInaïve patients treated with $\mathrm{RD}$ of alectinib in phase 1 were included in the population analysis for efficacy.

\section{Study approval}

This clinical trial was conducted in accordance with the Declaration of Helsinki (as revised in 2013) and the Harmonized Tripartite Guideline for Good Clinical Practice from the International Conference on Harmonization. This study was reviewed and approved by the institutional review boards of all participating institutions, including the Institutional Review Boards of the Kanazawa University Hospital (reference number: 9010) and was registered with UMIN Clinical Trials Registry (UMIN000020628). All patients enrolled completed the informed consent form.

\section{Results}

\section{Safety of alectinib}

Between February 2013 and January 2018, 4,552 patients with advanced non-squamous NSCLC enrolled in the LC-SCRUM-Japan study were screened for RET rearrangements. Among them, 119 patients (2.6\%) with RET-rearranged NSCLC were identified, and a total of 34 patients who met the eligibility criteria were enrolled in the present study. Characteristics of all patients in phase 1 and 2 are shown in Table 1. Lists of patients in phase 1 and 2 are 
Table 1 Patient baseline characteristics

\begin{tabular}{|c|c|c|c|}
\hline Characteristics & Total $(\mathrm{N}=34)$ & $\begin{array}{c}\text { Phase } 1 \\
(\mathrm{~N}=9)\end{array}$ & $\begin{array}{c}\text { Phase } 2 \\
(\mathrm{~N}=25)\end{array}$ \\
\hline \multicolumn{4}{|l|}{ Sex } \\
\hline Male & 14 & 3 & 11 \\
\hline Female & 20 & 6 & 14 \\
\hline \multicolumn{4}{|l|}{ Age } \\
\hline Median [range] & $53[30-78]$ & 60 [39-75] & $51[30-78]$ \\
\hline \multicolumn{4}{|l|}{ Smoking } \\
\hline Never & 22 & 6 & 16 \\
\hline Former & 12 & 3 & 9 \\
\hline Current & 0 & 0 & 0 \\
\hline \multicolumn{4}{|l|}{ Histology } \\
\hline Adenocarcinoma & 34 & 9 & 25 \\
\hline Other & 0 & 0 & 0 \\
\hline \multicolumn{4}{|l|}{ Type of RET fusion } \\
\hline KIF5B & 21 & 8 & 13 \\
\hline CCDC6 & 9 & 0 & 9 \\
\hline Unknown & 4 & 1 & 3 \\
\hline \multicolumn{4}{|l|}{ ECOG PS } \\
\hline 0 & 14 & 4 & 10 \\
\hline 1 & 20 & 5 & 15 \\
\hline 2 & 0 & 0 & 0 \\
\hline \multicolumn{4}{|c|}{ Brain metastases at baseline } \\
\hline Yes & 8 & 4 & 4 \\
\hline No & 26 & 5 & 21 \\
\hline \multicolumn{4}{|c|}{ Number of previous chemotherapy regimen } \\
\hline 1 & 7 & 1 & 6 \\
\hline 2 & 11 & 3 & 8 \\
\hline 3 and more & 16 & 5 & 11 \\
\hline \multicolumn{4}{|c|}{ Number of previous RET-TKI } \\
\hline 0 & 29 & 7 & 22 \\
\hline 1 & 3 & 2 & 1 \\
\hline 2 & 2 & 0 & 2 \\
\hline
\end{tabular}

shown in Table S1 and Table S2, respectively. All patients were in stage IV and had adenocarcinoma (Table 1). Of the 34 patients, 21 patients demonstrated KIF5B-RET, and 9 patients demonstrated CCDC6-RET, all of which were determined by NGS. In the remaining 4 patients, RET rearrangements were detected by multiplex RT-PCR, but the variant type was not determined as the samples were not available for NGS. All 34 patients were determined positive for RET rearrangements by break-apart-FISH analysis. Between March 8, 2016 and August 10, 2016, 9 patients were enrolled in phase 1 (Table S1). The first 3 patients in cohort 1 were administered a dose of $600 \mathrm{mg}$ BID oral alectinib. Since we observed DLTs (grade 3 rash and hepatic function abnormal) in one patient (case S1-3), we recruited 3 more patients into cohort 1; DLTs (grade 3 erythema multiforme and thromboembolic event in S14 , and grade 3 increase in CPK in S1-5) were observed in two of these additional patients (Table 2). The DLTs were improved by cessation of alectinib, steroid pulse therapy, and symptomatic therapy. Of the 6 patients treated with $600 \mathrm{mg}$ BID, grade 4 lymphocytopenia and grade 3 increase in ALP (Table 2) were observed in addition to DLTs. Since we observed DLTs in 3 of 6 patients, we reduced the dose of alectinib to $450 \mathrm{mg}$ BID in accordance with the protocol (Figure S1) and enrolled 3 patients in cohort 2. In cohort 2, we observed no DLTs. We therefore determined $450 \mathrm{mg}$ BID as the recommended alectinib dose for phase 2 .

Between September 28, 2016 and January 29, 2018, twenty-two RET-TKI-naïve patients and three previously RET-TKI-treated patients were enrolled in phase 2 (Table S2) and administered $450 \mathrm{mg}$ BID of alectinib. In the patients treated with $450 \mathrm{mg} \mathrm{BID}$, the major adverse events (AEs) were constipation, blood CPK, AST and creatinine increase; grade 3 AEs included diarrhea, pneumonitis, blood CPK and bilirubin increase, hyponatremia, and neutropenia; no grade $4 \mathrm{AEs}$ were observed (Table 2).

The treatment of 2 out of 6 patients treated with $600 \mathrm{mg}$ BID alectinib was discontinued due to DLTs (one patient had grade 3 erythema multiforme, another patient had grade 3 rash and grade 3 hepatic function abnormal). In contrast, the treatment of only 1 out of 28 patients treated with $450 \mathrm{mg}$ BID alectinib was discontinued due to pneumonitis and no patients required a dose reduction of alectinib due to toxicity.

\section{Pharmacokinetic analysis}

We analyzed blood samples from 9 patients in phase 1 and from the first 3 patients in phase 2 according to the protocol. On day 15, we evaluated 3 and 5 patients treated with $600 \mathrm{mg}$ BID and $450 \mathrm{mg}$ BID, respectively, since alectinib treatment was discontinued in some patients in phase 1 
Table 2 Main adverse events that occurred in the trial

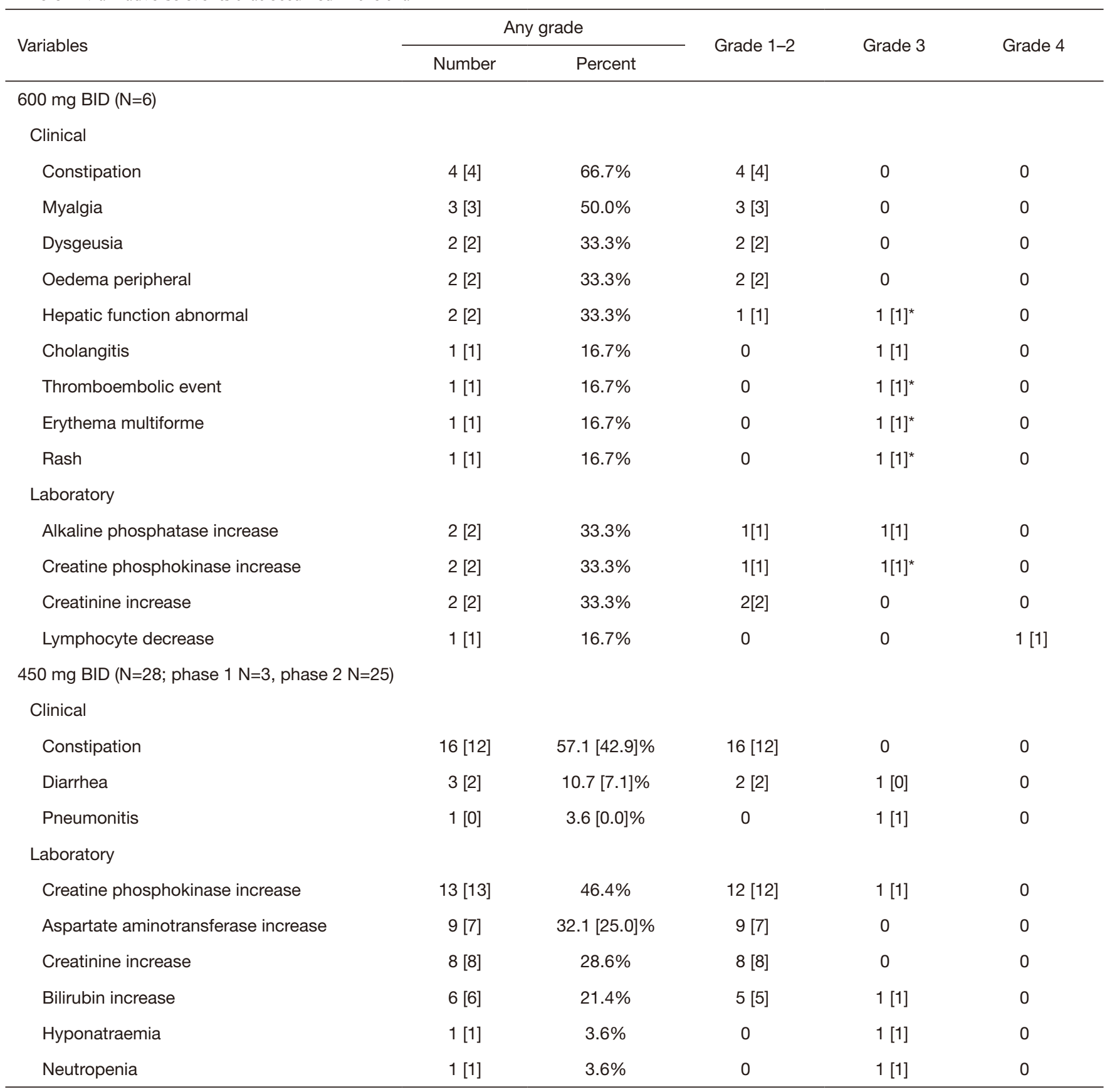

Total number [ ] is assessed as causally related . ${ }^{*}$, dose limiting toxicities.

due to toxicity. There was a dose-dependent increase in $\mathrm{C}_{\max }$ and $\mathrm{AUC}_{0-10}$ (Table 3). On day $15, \mathrm{C}_{\max }$ at $450 \mathrm{mg} \mathrm{BID}$ in ALL-RET $(576 \pm 215 \mathrm{ng} / \mathrm{mL})$ was almost comparable to $\mathrm{C}_{\max }$ at 460 and $600 \mathrm{mg}$ BID in the AF-002JG study (618 \pm 165 and $676 \pm 186 \mathrm{ng} / \mathrm{mL}$, respectively) (24). Notably, $\mathrm{C}_{\max }$ at $600 \mathrm{mg}$ BID in our study $(1,050 \pm$
$227 \mathrm{ng} / \mathrm{mL}$ ) was much higher than that in the global study (24). Similarly, while $\mathrm{AUC}_{0-10}$ at $450 \mathrm{mg}$ BID in our study $(4,820 \pm 1,970 \mathrm{ng} \cdot \mathrm{h} / \mathrm{mL})$ was comparable to those at $460 \mathrm{mg}$ and $600 \mathrm{mg}$ BID in the global study $(4,980 \pm 1,340$ and $5,400 \pm 1,400 \mathrm{ng} \cdot \mathrm{h} / \mathrm{mL}$, respectively), the $\mathrm{AUC}_{0-10}$ at $600 \mathrm{mg}$ BID in our study $(8,600 \pm 2,510 \mathrm{ng} \cdot \mathrm{h} / \mathrm{mL})$ was 
Table 3 Pharmacokinetic parameter

\begin{tabular}{lcccccc}
\hline & Dose of alectinib & $\mathrm{N}$ & \multicolumn{1}{c}{$\mathrm{T}_{\max }(\mathrm{h})$} & $\mathrm{C}_{\max }(\mathrm{ng} / \mathrm{mL})$ & $\mathrm{C}_{\min }(\mathrm{ng} / \mathrm{mL})$ & $\mathrm{AUC} \mathrm{C}_{0-10}(\mathrm{ng} \cdot \mathrm{h} / \mathrm{mL})$ \\
\hline Day 1 & $600 \mathrm{mg}$ & 6 & $7.01[3.98-9.98]$ & $366 \pm 102[253-527]$ & $278 \pm 76[201-417]$ & $1,710 \pm 587[1,060-2,440]$ \\
& $450 \mathrm{mg}$ & 6 & $5.91[4.0-7.93]$ & $165 \pm 93[23-272]$ & $118 \pm 55[12-165]$ & $927 \pm 517[143-1,570]$ \\
\multirow{2}{*}{ Day 15 } & $600 \mathrm{mg}$ & 3 & $5.77[0-6.0]$ & $1,050 \pm 227[788-1,210]$ & $911 \pm 281[587-1,080]$ & $8,600 \pm 2,510[5,800-10,600]$ \\
& $450 \mathrm{mg}$ & 5 & $7.97[4.0-8.0]$ & $576 \pm 215[304-840]$ & $483 \pm 192[271-785]$ & $4,820 \pm 1,970[2,440-7,460]$ \\
\hline
\end{tabular}

$\mathrm{T}_{\max }=$ time to maximum concentration, median [min-max]. $\mathrm{C}_{\max }=$ maximum plasma concentration, arithmetic mean \pm SD (standard deviation) [min-max]. $\mathrm{C}_{\min }=$ plasma concentration at $10 \mathrm{~h}$ after drug administration, arithmetic mean $\pm \mathrm{SD}[\mathrm{min}-\mathrm{max}] . \mathrm{AUC}_{0-10}=\operatorname{area} u$ under plasma-concentration time curve from 0-10 h, arithmetic mean \pm SD [min-max].

Table 4 Efficacy of alectinib in RET-TKI naïve patients

\begin{tabular}{lc}
\hline Best overall response & RET-TKI-naïve $(\mathrm{n}=25), \mathrm{n}(\%)$ \\
\hline CR & 0 \\
PR & $1(4 \%)$ \\
SD & $12(48 \%)$ \\
PD & $10(40 \%)$ \\
NE & $2(8 \%)$ \\
\hline
\end{tabular}

ORR: 4\% (95\% Cl: 0.1-20.4); DCR: 52\% (95\% Cl: 31.3-72.2). $\mathrm{CR}$, complete response; PR, partial response; SD, stable disease; PD, progressive disease; NE, not evaluated; ORR, overall response rate; $\mathrm{DCR}$, disease control rate; $\mathrm{Cl}$, confidence interval.

higher than that in the global study (25). These results suggest that alectinib at $600 \mathrm{mg}$ BID might be an excessive dose for Japanese patients with RET-rearranged NSCLC.

\section{Efficacy of alectinib}

We assessed antitumor efficacy by central review of 25 patients in phase 2 and 3 patients (all of whom were RETTKI naïve) treated with $450 \mathrm{mg}$ BID alectinib in cohort 2 of phase 1 . In 25 RET-TKI-naïve patients (3 patients in phase 1 cohort 2 and 22 patients in phase 2), the overall response rate was $4 \%(1 / 25)$. The DCR was $52 \%(13 / 25)$ (Table 4$)$. The median PFS and OS of 25 RET-TKI-naïve patients treated with alectinib at $450 \mathrm{mg}$ BID was 3.4 months ( $95 \%$ CI: 2.0-5.4) and 19 months (95\% CI: 5.4-NE), respectively (Figure 1).

The swimmer plot of 34 patients in phase 1 and phase 2 is shown in Figure 2A. Early treatment interruptions or dose reductions were required for 5 of the 6 patients treated with alectinib at $600 \mathrm{mg}$ BID in phase 1 due to drug-related toxicities including DLTs. However, alectinib at $450 \mathrm{mg}$
BID was tolerable and 5 patients could continue treatment for more than 1 year. KIFSB-RET was the most common fusion gene (21/34 cases, $61.8 \%$ ), and the CCDC6-RET fusion was identified in 9 cases (26.5\%). RET-fusion type did not affect the alectinib treatment duration. The spider plot of 34 patients, including all of 6 patients in phase 1 whose efficacy could be assessed, is shown in Figure 2B. One male patient with KIF5B-RET rearrangement who showed $\mathrm{PR}$ in phase 2 was treated for almost 2 years, suggesting the clinical benefit of alectinib for this individual.

\section{Discussion}

In the present study, we determined that the MTD of alectinib was $450 \mathrm{mg}$ BID for Japanese patients with RETrearranged NSCLC. Pharmacokinetic analysis revealed that the $\mathrm{C}_{\max }$ and $\mathrm{AUC}_{0-10}$ of alectinib in Japanese patients with RET-rearranged NSCLC who received 450 and $600 \mathrm{mg}$ BID were comparable with and higher than, respectively, those with $A L K$-rearranged NSCLC administered $600 \mathrm{mg}$ BID in a global study (25). The reasons for this are unclear; however, one possible explanation involves the small body mass index of the patients in our study. Of the 9 patients in phase 1 and the first 3 patients in phase 2, 10 out of 12 weighed $60 \mathrm{~kg}$ or less. In the global study for $A L K$ rearranged NSCLC, high interpatient variability in $\mathrm{C}_{\max }$ and AUC was reported among individuals receiving $900 \mathrm{mg}$ BID alectinib (25). Thus, body size might require consideration when a high dose of alectinib is administered.

In the present study, a marked antitumor effect was not observed in 25 relatively heavily-treated (mean previous regimen was 2.9) RET-TKI-naïve patients or in 3 patients previously treated with RET-TKIs who subsequently received the $\mathrm{RD}$ of alectinib (450 mg BID). However, a considerable and durable antitumor effect was observed in one male patient who was previously treated with one 

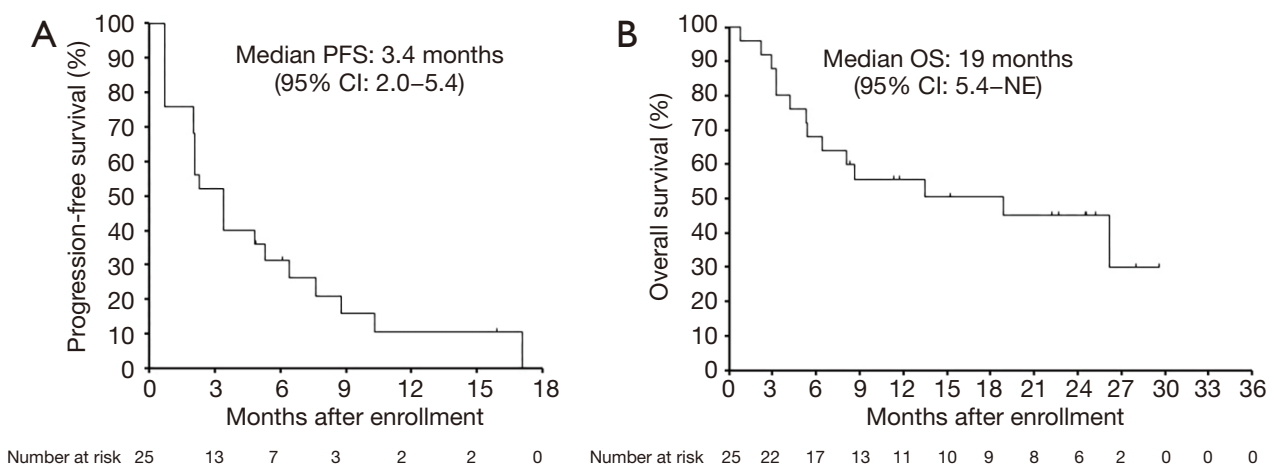

Figure 1 PFS and OS of RET-TKI-naïve patients treated with $450 \mathrm{mg}$ BID alectinib. The Kaplan-Meier curves estimating PFS (A) and OS (B) of 25 RET-TKI-naïve NSCLC patients (3 in phase 1 and 22 in phase 2) are shown. OS, overall survival; RET-TKI, rearranged during transfection-tyrosine kinase inhibitor; PFS, progression-free survival; NSCLC, non-small cell lung cancer.

regimen of chemotherapy but not with RET-TKIs. In addition, disease stabilization for a period more than 1 year was observed in 5 patients (20\%). In studies of nonJapanese RET rearrangement NSCLC, PR was observed in 4 out of 8 patients treated with $600 \mathrm{mg}$ BID alectinib $(30,31)$. These results suggest that alectinib may be effective in a subpopulation of NSCLC with RET rearrangement and that a biomarker for efficacy is necessary to further develop alectinib in RET-rearranged NSCLC.

The free fraction of $\mathrm{Cmin}$ in a steady state of alectinib $450 \mathrm{mg}$ BID $(<4.8 \mathrm{ng} / \mathrm{mL}$, equivalent to $<10 \mathrm{nmol} / \mathrm{L})$ treatment would be comparable to the half-maximum inhibitory concentration (IC50) of RET kinase ( $4.8 \mathrm{nmol} / \mathrm{L}$ ) and much lower than that in the RET-fusion positive NSCLC cells $(<300 \mathrm{nmol} / \mathrm{L})(20,21)$. Therefore, this can be one of the reasons why alectinib showed limited activity against NSCLC with RET rearrangement. Recent studies reported that inhibition of driver signals from BRAF, KRAS, or EGFR by their corresponding inhibitors causes reactivation of proliferation and/or survival signals, such as ERK and AKT, through feedback mechanisms (32-34) and therefore induces drug tolerance. In addition, the resistance to ponatinib, a multi-kinase inhibitor with RET inhibitory activity, could be emerged by reactivation of RAS/MAPK signaling via NRAS mutation or activation of EGFR and AXL (35). We found in the preclinical studies that suppression of RET by specific shRNA in CCDC6RET-positive LC2/ad cells increased HER2 activation
(Figure S2A) and that combined use of afatinib, which can inhibit HER2, caused marked apoptosis (Figure S2B). Moreover, afatinib discernibly sensitized LC2/ad cells to alectinib in vitro (Figure S2C). These results suggest that combined use of alectinib and an inhibitor against such feedback mechanisms may be necessary for a marked antitumor effect in NSCLC with RET rearrangement. Recent clinical trials demonstrated that the potent RET inhibitors selpercatinib (LOXO-292) (36) and pralsetinib (BLU-667) (37) showed a high response rate and prolonged PFS in patients with NSCLC with RET rearrangement. Despite of unprecedented efficacy, emergence of acquired resistance to selpercatinib via solvent front mutations in $R E T$ has been reported (38). Therefore, further analyses are warranted to elucidate the mechanisms underlying sensitivity and resistance of RET inhibitors to further improve outcomes for NSCLC with RET rearrangement.

\section{Conclusions}

We completed a phase $1 / 2$ study of alectinib in RETrearranged advanced NSCLC in Japanese patients and determined the MTD of alectinib (450 mg BID). Alectinib had limited activity in patients with RET-rearranged NSCLC. Further investigation to elucidate the mechanisms underlying sensitivity and resistance of RET inhibitors is required to improve outcomes for these patients. 

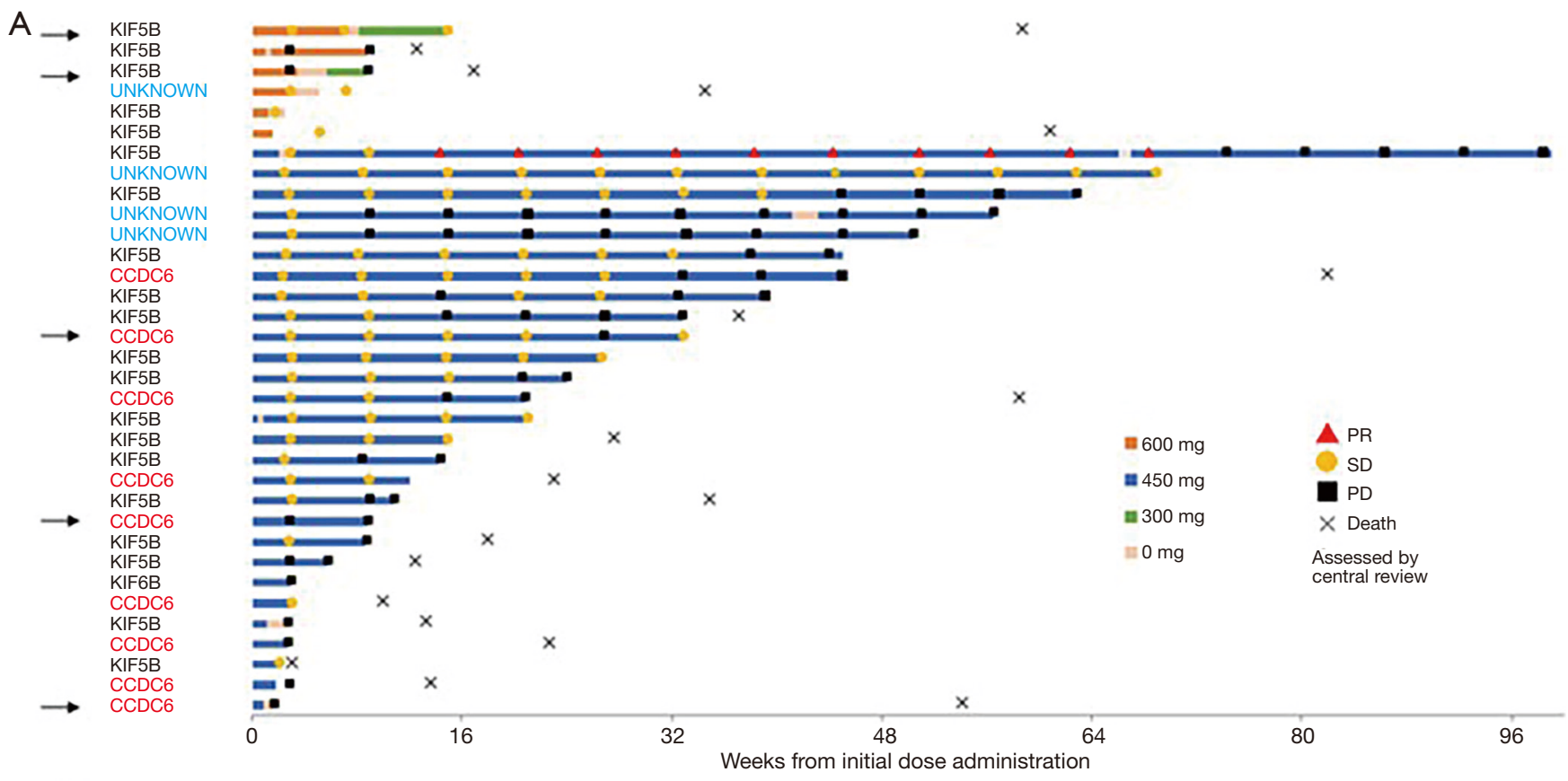

$\longrightarrow$ Previously treated with other RET-TKIs

B

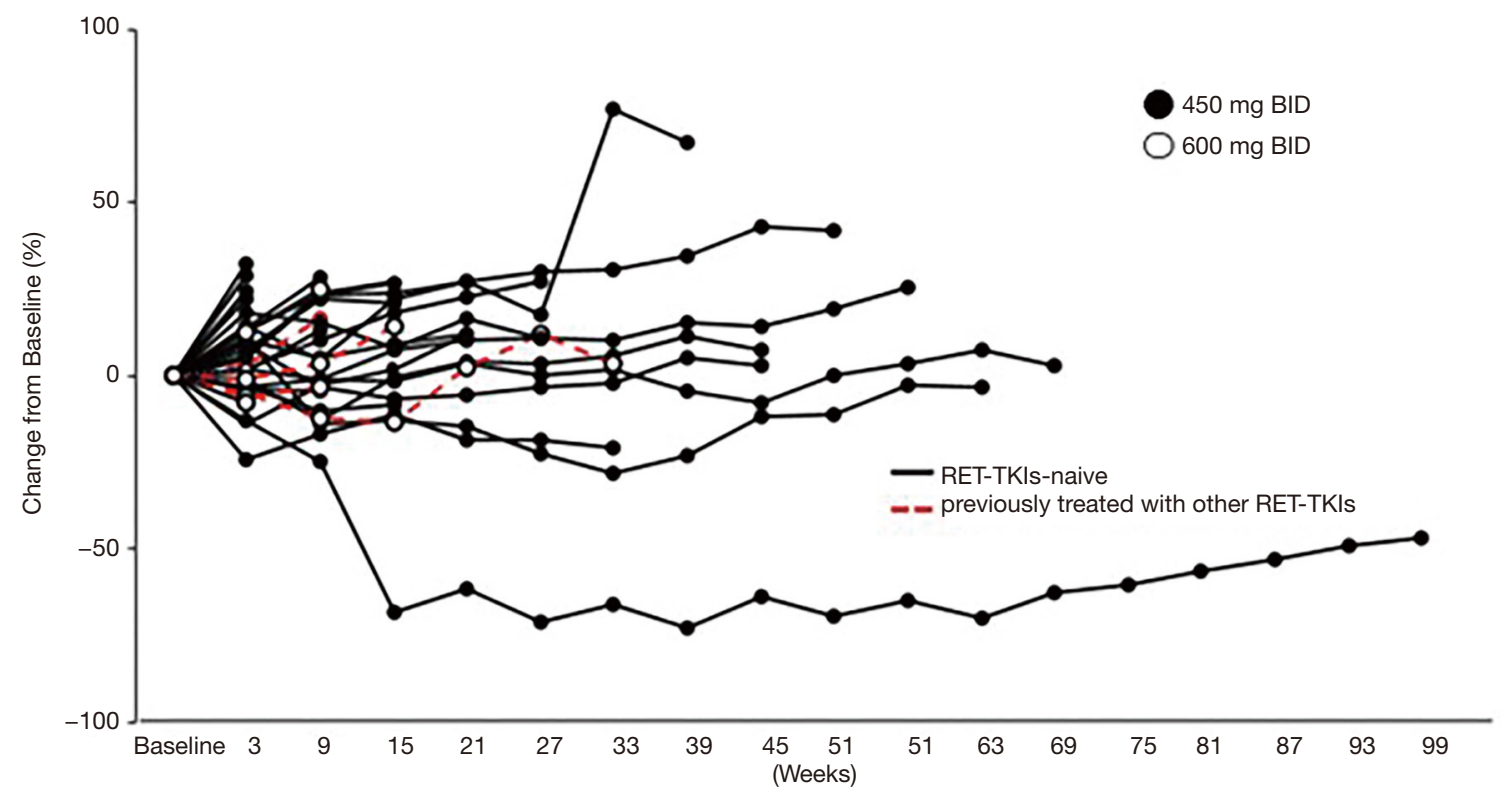

Figure 2 Clinical outcome of RET rearranged NSCLC patients treated with alectinib. (A) Swimmer plot of all patients treated with alectinib. Bars indicate duration of alectinib treatment. The response [partial response (PD), stable disease (SD) and progressive disease (PD)] in 34 patients (9 in phase 1 and 25 in phase 2) was assessed by central review (RECIST v1.1). The fusion partner for RET in each patient is shown on the left side of the bars. Arrows indicate patients who were previously treated with other RET-TKIs. (B) Spider plot of all patients treated with alectinib. RET, rearranged during transfection; NSCLC, non-small cell lung cancer. 


\section{Acknowledgments}

We thank the patients, their families, and all staff that participated in this study. We are grateful to Chugai Pharmaceutical for providing alectinib compassionately.

Funding: This study was supported by grants from the Japan Agency for Medical Research and Development, AMED, Grant Number 15Ack0106147h0001 and 18ck0106423h0001 (to SY) and Kanazawa University Hospital.

\section{Footnote}

Reporting Checklist: The authors have completed the TREND reporting checklist. Available at http://dx.doi. org/10.21037/tlcr-20-549

Data Sharing Statement: Available at http://dx.doi. org/10.21037/tlcr-20-549

Peer Review File: Available at http://dx.doi.org/10.21037/ tlcr-20-549

Conflicts of Interest: All authors have completed the ICMJE uniform disclosure form (available at http://dx.doi. org/10.21037/tlcr-20-549). Dr. NY, Dr. YH, and Dr. MM reports personal fees from Chugai Pharma, outside the submitted work. Dr. TS reports grants and personal fees from Chugai Pharma, grants and personal fees from AstraZeneca, grants and personal fees from Eisai, grants and personal fees from Eli Lilly Japan, grants and personal fees from Nippon Boehringer Ingelheim, grants and personal fees from Novartis Pharma, grants and personal fees from Pfizer Japan, grants and personal fees from Sanofi, grants and personal fees from Taiho Pharma, personal fees from Daiichi Sankyo, personal fees from Fuji Pharma, personal fees from Hisamitsu Pharma, personal fees from Kyowa Hakko Kirin, personal fees from Mochida Pharma, personal fees from Nippon Kayaku, personal fees from Ono Pharma, personal fees from Roche Diagnostics, personal fees from Showa Yakuhin Kako, personal fees from Sumitomo Dainippon Pharma, personal fees from Takeda Pharma, grants from Astellas Pharma, grants from Bayer Yakuhin, grants from Merck Serono, grants from MSD, grants from Verastem, grants from Yakult, outside the submitted work. Dr. SM reports grants and personal fees from Astellas Pharma, grants and personal fees from Novartis Pharma, grants and personal fees from Eli Lilly Japan, grants from
Chugai Pharma, grants from AstraZeneca, grants from Amgen Astellas BioPharma, grants from Eisai, grants from Ono Pharma, grants from Kyowa Hakko Kirin, grants from MSD, grants from Daiichi Sankyo, grants from Taiho Pharma, grants from Takeda Pharma, grants from Pfizer, outside the submitted work. Dr. K Yoh reports grants and personal fees from AstraZeneca, grants and personal fees from Eli Lilly Japan, personal fees from Boehringer Ingelheim, personal fees from Pfizer, personal fees from Taiho Pharma, personal fees from Bristol-Myers Squibb, personal fees from Ono Pharma, grants from Bayer, grants from Novartis, grants from Takeda Pharma, outside the submitted work. Dr. KG reports grants and personal fees from Chugai, grants and personal fees from Taiho Pharma, grants and personal fees from AstraZeneca, grants and personal fees from Nippon Boehringer Ingelheim, grants and personal fees from Ono Pharma, grants and personal fees from Pfizer, grants and personal fees from Kyowa Hakko Kirin, grants and personal fees from Eli Lilly Japan, grants and personal fees from Daiichi Sankyo, grants from MSD, grants from Quintiles, grants from GlaxoSmithKline, grants from OxOnc, grants from Sumitomo Dainippon Pharma, grants from Takeda Pharma, grants from Astellas Pharma, grants from Eisai, grants from Amgen Astellas BioPharma, personal fees from Yakult Honsha, personal fees from Novartis Pharma, personal fees from BristolMyers Squibb, outside the submitted work. Dr. MN reports grants and personal fees from Chugai, grants and personal fees from Taiho Pharma, grants and personal fees from AstraZeneca, grants and personal fees from Bristol Myers Squibb, grants and personal fees from Ono Pharma, grants and personal fees from Pfizer, grants and personal fees from Novartis, grants and personal fees from Eli Lilly Japan, grants and personal fees from MSD, personal fees from Boehringer-Ingelheim, personal fees from Daiichi Sankyo Healthcare, personal fees from Merck Serono, personal fees from MSD, personal fees from Pfizer, grants from Astellas, outside the submitted work. Dr. K Yoshimura reports personal fees from Chugai Pharma, personal fees from Astra Zeneca, personal fees from Eli Lilly, outside the submitted work. Dr. SY reports grants from the Japan Agency for Medical Research and Development (AMED), during the conduct of the study; grants and personal fees from Chugai Pharma, grants and personal fees from BoehringerIngelheim Japan, grants and personal fees from Novartis, personal fees from AstraZeneca, personal fees from Pfizer, outside the submitted work. The other authors have no conflicts of interest to declare. 
Ethical Statement: The authors are accountable for all aspects of the work in ensuring that questions related to the accuracy or integrity of any part of the work are appropriately investigated and resolved. This clinical trial was conducted in accordance with the Declaration of Helsinki (as revised in 2013) and the Harmonized Tripartite Guideline for Good Clinical Practice from the International Conference on Harmonization. This study was reviewed and approved by the institutional review boards of all participating institutions, including the Institutional Review Boards of the Kanazawa University Hospital (reference number: 9010) and was registered with UMIN Clinical Trials Registry (UMIN000020628). All patients enrolled completed the informed consent form.

Open Access Statement: This is an Open Access article distributed in accordance with the Creative Commons Attribution-NonCommercial-NoDerivs 4.0 International License (CC BY-NC-ND 4.0), which permits the noncommercial replication and distribution of the article with the strict proviso that no changes or edits are made and the original work is properly cited (including links to both the formal publication through the relevant DOI and the license). See: https://creativecommons.org/licenses/by-nc-nd/4.0/.

\section{References}

1. Kohno T, Nakaoku T, Tsuta K, et al. Beyond ALK-RET, ROS1 and other oncogene fusions in lung cancer. Transl Lung Cancer Res 2015;4:156-64.

2. Maemondo M, Inoue $A$, Kobayashi $K$, et al. Gefitinib or chemotherapy for non-small-cell lung cancer with mutated EGFR. N Engl J Med 2010;362:2380-8.

3. Mitsudomi T, Morita S, Yatabe Y, et al. Gefitinib versus cisplatin plus docetaxel in patients with non-small-cell lung cancer harbouring mutations of the epidermal growth factor receptor (WJTOG3405): an open label, randomised phase 3 trial. Lancet Oncol 2010;11:121-8.

4. Soria JC, Ohe Y, Vansteenkiste J, et al. Osimertinib in untreated EGFR-mutated advanced non-small-cell lung cancer. N Engl J Med 2018;378:113-25.

5. Shaw AT, Kim DW, Nakagawa K, et al. Crizotinib versus chemotherapy in advanced ALK-positive lung cancer. $\mathrm{N}$ Engl J Med 2013;368:2385-94.

6. Hida T, Nokihara H, Kondo M, et al. Alectinib versus crizotinib in patients with ALK-positive non-small-cell lung cancer (J-ALEX): an open-label, randomised phase 3 trial. Lancet 2017;390:29-39.
7. Shaw AT, Ou SH, Bang YJ, et al. Crizotinib in ROS1 rearranged non-small-cell lung cancer. $\mathrm{N}$ Engl J Med 2014;371:1963-71.

8. Farago AF, Le LP, Zheng Z, et al. Durable clinical response to entrectinib in NTRK1-rearranged non-small cell lung cancer. J Thorac Oncol 2015;10:1670-4.

9. Takahashi M, Ritz J, Cooper GM. Activation of a novel human transforming gene, ret, by DNA rearrangement. Cell 1985;42:581-8.

10. Zhu Z, Ciampi R, Nikiforova $M N$, et al. Prevalence of RET/PTC rearrangements in thyroid papillary carcinomas: effects of the detection methods and genetic heterogeneity. J Clin Endocrinol Metab 2006;91:3603-10.

11. Ciampi R, Nikiforov YE. RET/PTC rearrangements and BRAF mutations in thyroid tumorigenesis. Endocrinology 2007;148:936-41.

12. Ju YS, Lee WC, Shin JY, et al. A transforming KIF5B and RET gene fusion in lung adenocarcinoma revealed from whole-genome and transcriptome sequencing. Genome Res 2012;22:436-45.

13. Kohno T, Ichikawa H, Totoki Y, et al. KIF5B-RET fusions in lung adenocarcinoma. Nat Med 2012;18:375-7.

14. Takeuchi K, Soda M, Togashi Y, et al. RET, ROS1 and ALK fusions in lung cancer. Nat Med 2012;18:378-81.

15. Lipson D, Capelletti M, Yelensky R, et al. Identification of new ALK and RET gene fusions from colorectal and lung cancer biopsies. Nat Med 2012;18:382-4.

16. Wang $\mathrm{R}, \mathrm{Hu} \mathrm{H}$, Pan $\mathrm{Y}$, et al. RET fusions define a unique molecular and clinicopathologic subtype of non-small-cell lung cancer. J Clin Oncol 2012;30:4352-9.

17. Drilon A, Wang L, Hasanovic A, et al. Response to cabozantinib in patients with RET fusion-positive lung adenocarcinomas. Cancer Discov 2013;3:630-5.

18. Saito $M$, Ishigame $T$, Tsuta $K$, et al. A mouse model of KIF5B-RET fusion-dependent lung tumorigenesis. Carcinogenesis 2014;35:2452-6.

19. Yoh K, Seto T, Satouchi M, et al. Vandetanib in patients with previously treated RET-rearranged advanced non-small-cell lung cancer (LURET): an open-label, multicentre phase 2 trial. Lancet Respir Med 2017;5:42-50.

20. Drilon A, Rekhtman N, Arcila M, et al. Cabozantinib in patients with advanced RET-rearranged non-small-cell lung cancer: an open-label, single-centre, phase 2, singlearm trial. Lancet Oncol 2016;17:1653-60.

21. Sakamoto H, Tsukaguchi T, Hiroshima S, et al. CH5424802, a selective ALK inhibitor capable of blocking the resistant gatekeeper mutant. Cancer Cell 
2011;19:679-90.

22. Kodama T, Tsukaguchi T, Satoh Y, et al. Alectinib shows potent antitumor activity against RET-rearranged nonsmall cell lung cancer. Mol Cancer Ther 2014;13:2910-8.

23. Arai S, Kita K, Tanimoto A, et al. In vitro and in vivo antitumor activity of alectinib in tumor cells with NCOA4RET. Oncotarget 2017;8:73766-73.

24. Seto T, Kiura K, Nishio M, et al. CH5424802 (RO5424802) for patients with ALK-rearranged advanced non-small-cell lung cancer (AF-001JP study): a single-arm, open-label, phase 1-2 study. Lancet Oncol 2013;14:590-8.

25. Gadgeel SM, Gandhi L, Riely GJ, et al. Safety and activity of alectinib against systemic disease and brain metastases in patients with crizotinib-resistant ALK-rearranged non-small-cell lung cancer (AF-002JG): results from the dose-finding portion of a phase 1/2 study. Lancet Oncol 2014;15:1119-28.

26. Shaw AT, Gandhi L, Gadgeel S, et al. Alectinib in ALKpositive, crizotinib-resistant, non-small-cell lung cancer: a single-group, multicentre, phase 2 trial. Lancet Oncol 2016;17:234-42.

27. Takeuchi S, Murayama T, Yoshimura K, et al. Phase I/II study of alectinib in lung cancer with RET fusion gene: study protocol. J Med Invest 2017;64:317-20.

28. Eisenhauer EA, Therasse P, Bogaerts J, et al. New response evaluation criteria in solid tumours: revised RECIST guideline (version 1.1). Eur J Cancer 2009;45:228-47.

29. Hida T, Nakagawa K, Seto T, et al. Pharmacologic study (JP28927) of alectinib in Japanese patients with ALK+ non-small-cell lung cancer with or without prior crizotinib therapy. Cancer Sci 2016;107:1642-6.

30. Lin JJ, Kennedy E, Sequist LV, et al. Clinical activity of alectinib in advanced RET-rearranged non-small cell lung

Cite this article as: Takeuchi S, Yanagitani N, Seto T, Hattori Y, Ohashi K, Morise M, Matsumoto S, Yoh K, Goto K, Nishio M, Takahara S, Kawakami T, Imai Y, Yoshimura K, Tanimoto A, Nishiyama A, Murayama T, Yano S. Phase 1/2 study of alectinib in RET-rearranged previously-treated nonsmall cell lung cancer (ALL-RET). Transl Lung Cancer Res 2021;10(1):314-325. doi: 10.21037/tlcr-20-549 cancer. J Thorac Oncol 2016;11:2027-32.

31. Ribeiro M, Gongora A, Oliveira L, et al. Metastatic RETrearranged lung adenocarcinomas treated with alectinib: retrospective analysis of a single institution (P2. 1467). Presented at Would Conference for Lung Cancer, Barcelona, Spain, September 6-10, 2019.

32. Yao Z, Torres NM, Tao A, et al. BRAF Mutants evade ERK-dependent feedback by different mechanisms that determine their sensitivity to pharmacologic inhibition. Cancer Cell 2015;28:370-83.

33. Kitai H, Ebi H, Tomida S, et al. Epithelial-tomesenchymal transition defines feedback activation of receptor tyrosine kinase signaling induced by MEK inhibition in KRAS mutant lung cancer. Cancer Discov 2016;6:754-69.

34. Taniguchi H, Yamada T, Wang R, et al. AXL confers intrinsic resistance to osimertinib and advances the emergence of tolerant cells. Nat Commun 2019;10:259.

35. Nelson-Taylor SK, Le AT, Yoo M, et al. Resistance to RET-inhibition in RET-rearranged NSCLC is mediated by reactivation of RAS/MAPK signaling. Mol Cancer Ther 2017;16:1623-33.

36. Subbiah V, Velcheti V, Tuch BB, et al. Selective RET kinase inhibition for patients with RET-altered cancers. Ann Oncol 2018;29:1869-76.

37. Subbiah V, Gainor JF, Rahal R, et al. Precision targeted therapy with BLU-667 for RET-driven cancers. Cancer Discov 2018;8:836-49.

38. Solomon BJ, Tan L, Lin JJ, et al. RET solvent front mutations mediate acquired resistance to selective RET inhibition in RET-driven malignancies. J Thorac Oncol 2020;15:541-9. 


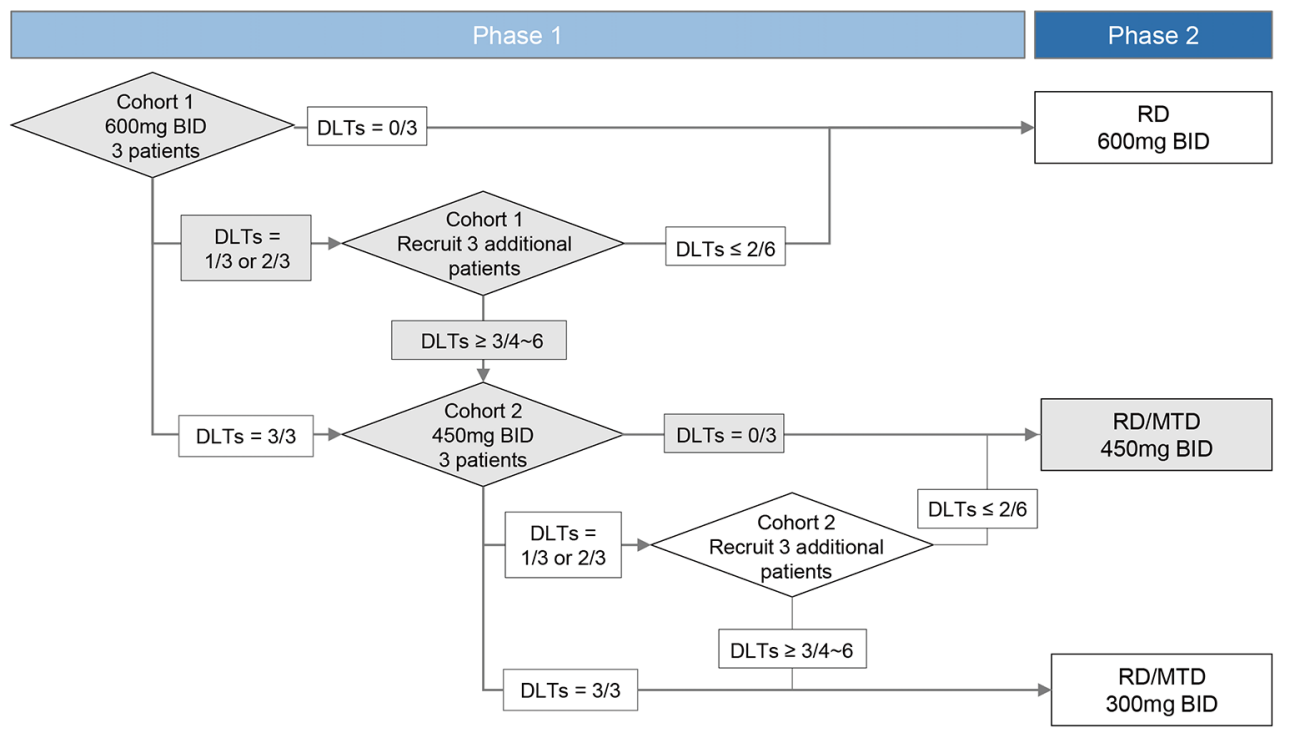

Figure S1 Study design. Grey areas indicate actual outcome and dose reduction of this study. BID, administered twice daily; DLTs, dose limiting toxicities; RD, recommended dose; MTD, maximum tolerated dose. This figure was from the reference (25).

Table S1 List of patients in phase 1

\begin{tabular}{|c|c|c|c|c|c|c|c|c|c|c|c|}
\hline $\begin{array}{l}\text { Cohort } \\
\text { (alectinib dose) }\end{array}$ & Case & Age & Sex & $\begin{array}{l}\text { Smoking } \\
\text { status }\end{array}$ & $\begin{array}{l}\text { Type of RET } \\
\text { fusion }\end{array}$ & PS & $\begin{array}{c}\text { Body } \\
\text { weight }(\mathrm{kg})\end{array}$ & $\begin{array}{l}\text { Previous RET-TKI } \\
\text { treatment }\end{array}$ & $\begin{array}{c}\text { Previous } \mathrm{ICl} \\
\text { treatment }\end{array}$ & $\begin{array}{l}\text { No. of previous } \\
\text { regimens }\end{array}$ & DLTs \\
\hline \multirow{6}{*}{$\begin{array}{l}\text { Cohort } 1 \\
\text { (600 mg BID) }\end{array}$} & $\mathrm{S} 1-1$ & 53 & $\mathrm{~F}$ & Never & KIF5B- RET & 0 & 67 & - & - & 2 & - \\
\hline & S1-2 & 64 & $\mathrm{~F}$ & Former & KIF5B- RET & 1 & 45 & Vandetanib & - & 3 & - \\
\hline & $\mathrm{S} 1-3$ & 47 & $\mathrm{~F}$ & Never & KIF5B- RET & 1 & 60 & - & Nivolumab & 5 & Rash, AST increased \\
\hline & $S 1-4$ & 39 & $\mathrm{~F}$ & Never & KIF5B- RET & 1 & 55 & - & Nivolumab & 8 & $\begin{array}{l}\text { Erythema multiforme, } \\
\text { Thromboembolic event }\end{array}$ \\
\hline & $S 1-5$ & 61 & $\mathrm{~F}$ & Never & KIF5B- RET & 1 & 46 & Vandetanib & - & 3 & - \\
\hline & S1-6 & 73 & M & Former & Unknown & 1 & 54 & - & - & 2 & CPK Increased \\
\hline \multirow{3}{*}{$\begin{array}{l}\text { Cohort } 2 \\
\text { (450 mg BID) }\end{array}$} & $\mathrm{S} 1-7$ & 68 & $\mathrm{~F}$ & Never & KIF5B- RET & 0 & 58 & - & - & 1 & - \\
\hline & $S 1-8$ & 58 & $M$ & Never & KIF5B- RET & 0 & 53 & - & - & 4 & - \\
\hline & S1-9 & 75 & $M$ & Former & KIF5B- RET & 0 & 63 & - & - & 2 & - \\
\hline
\end{tabular}

PS, performance status; ICI, immune checkpoint inhibitor; DLTs, dose-limiting toxicities; F, female; M, male. 
Table S2 List of patients in phase 2

\begin{tabular}{|c|c|c|c|c|c|c|c|c|c|}
\hline Case & Age & Sex & $\begin{array}{l}\text { Smoking } \\
\text { status }\end{array}$ & $\begin{array}{l}\text { Type of RET } \\
\text { fusion }\end{array}$ & $\begin{array}{l}\text { ECOG } \\
\text { PS }\end{array}$ & $\begin{array}{l}\text { Body } \\
\text { weight }\end{array}$ & $\begin{array}{l}\text { Previous RET-TKI } \\
\text { treatment }\end{array}$ & $\begin{array}{l}\text { Previous } \mathrm{ICl} \\
\text { treatment }\end{array}$ & $\begin{array}{c}\text { Number of previous } \\
\text { regimens }\end{array}$ \\
\hline S2-1 & 69 & M & Former & KIF5B-RET & 1 & 48 & - & - & 1 \\
\hline S2-2 & 67 & $\mathrm{~F}$ & Never & Unknown & 1 & 48 & - & - & 2 \\
\hline S2-3 & 66 & $\mathrm{~F}$ & Never & KIF5B-RET & 1 & 56 & - & - & 3 \\
\hline S2-4 & 47 & $\mathrm{~F}$ & Never & CCDC6-RET & 1 & 59 & $\begin{array}{l}\text { Vandetanib, } \\
\text { lenvatinib }\end{array}$ & - & 5 \\
\hline$S 2-5$ & 36 & M & Never & CCDC6-RET & 1 & 56 & - & Avelumab & 3 \\
\hline S2-6 & 61 & M & Former & KIF5B-RET & 1 & 87 & - & - & 1 \\
\hline S2-7 & 46 & M & Former & KIF5B-RET & 0 & 82 & - & - & 1 \\
\hline S2-8 & 52 & M & Never & Unknown & 0 & 70 & - & - & 1 \\
\hline S2-9 & 67 & $\mathrm{~F}$ & Former & CCDC6-RET & 0 & 75 & - & - & 2 \\
\hline S2-10 & 33 & $\mathrm{~F}$ & Never & KIF5B-RET & 1 & 54 & - & - & 1 \\
\hline$S 2-11$ & 44 & M & Former & CCDC6-RET & 0 & 73 & $\begin{array}{l}\text { Vandetanib, } \\
\text { lenvatinib }\end{array}$ & - & 5 \\
\hline S2-12 & 46 & $\mathrm{~F}$ & Never & KIF5B-RET & 0 & 73 & - & - & 2 \\
\hline$S 2-13$ & 54 & $\mathrm{~F}$ & Never & Unknown & 1 & 62 & - & - & 3 \\
\hline S2-14 & 30 & $M$ & Never & CCDC6-RET & 1 & 65 & - & - & 3 \\
\hline $\mathrm{S} 2-15$ & 39 & $\mathrm{~F}$ & Never & KIF5B-RET & 1 & 69 & - & - & 2 \\
\hline S2-16 & 44 & $\mathrm{~F}$ & Former & CCDC6-RET & 0 & 57 & - & - & 1 \\
\hline S2-17 & 78 & $\mathrm{~F}$ & Never & KIF5B-RET & 1 & 52 & - & - & 2 \\
\hline S2-18 & 59 & $\mathrm{~F}$ & Never & KIF5B-RET & 0 & 80 & - & Nivolumab & 3 \\
\hline S2-19 & 30 & M & Former & CCDC6-RET & 1 & 90 & - & - & 2 \\
\hline S2-20 & 34 & M & Former & KIF5B-RET & 0 & 86 & - & Pembrolizumab & 2 \\
\hline S2-21 & 57 & $\mathrm{~F}$ & Former & CCDC6-RET & 0 & 41 & Vandetanib & - & 4 \\
\hline S2-22 & 70 & $\mathrm{~F}$ & Never & KIF5B-RET & 1 & 51 & - & Pembrolizumab & 2 \\
\hline$S 2-23$ & 53 & M & Never & KIF5B-RET & 1 & 63 & - & - & 3 \\
\hline S2-24 & 37 & $\mathrm{~F}$ & Never & KIF5B-RET & 0 & 55 & - & Nivolumab & 3 \\
\hline S2-25 & 44 & M & Never & CCDC6-RET & 1 & 63 & - & Nivolumab & 5 \\
\hline
\end{tabular}

PS, performance status; ICl, immune checkpoint inhibitor; M, male; F, female.

A

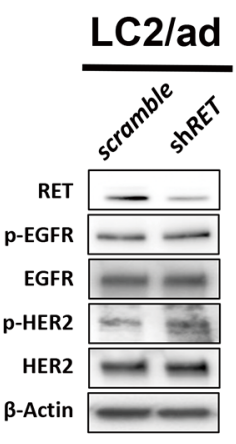

B

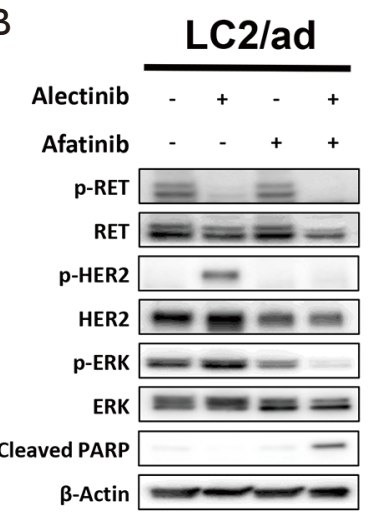

C

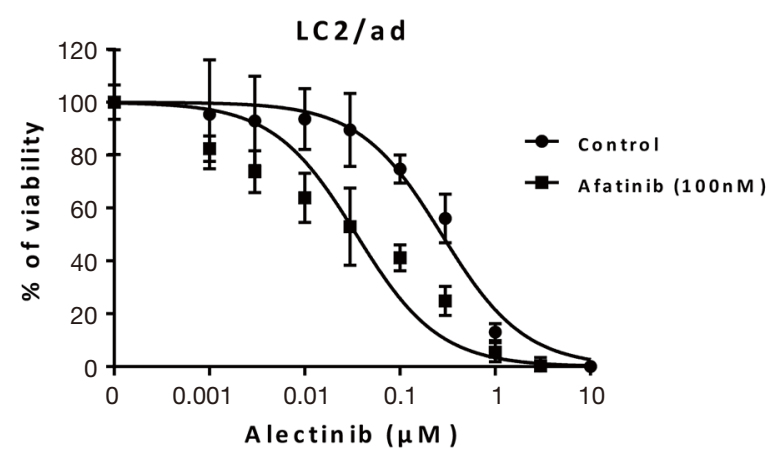

Figure S2 Alectinib exposure induced activation of HER2 in the RET-fusion positive NSCLC cell line LC2/ad. (A) Western blotting of LC2/ad cells treated with shRNA targeting RET. (B) Protein expression by western blotting in LC2/ad cells treated with alectinib (1 $\mu \mathrm{mol} / \mathrm{L})$ and/or afatinib (100 nmol/L) for $72 \mathrm{~h}$. (C) Cell viability determined by MTT assay in LC2/ad cells after $72 \mathrm{~h}$ treatment with combination of alectinib and afatinib. Data shown are representative of at least three independent experiments. The data shown are the mean \pm SD of triplicate cultures. RET, rearranged during transfection; NSCLC, non-small cell lung cancer. 